\title{
The Impacts of Water Pricing and Non-Pricing Policies on Sustainable Water Resources Management: A Case of Ghorveh Plain at Kurdistan Province, Iran
}

\author{
Mohammad Ali Asaadi ${ }^{1}$, Seyed Abolghasem Mortazavi ${ }^{1, *}$, Omid Zamani ${ }^{2,3}$, \\ Gholam Hassan Najafi ${ }^{4}$, Talal Yusaf ${ }^{5,6}$ and Seyed Salar Hoseini ${ }^{4}$ \\ 1 Department of Agricultural Economics, Tarbiat Modares University, Tehran 14115-336, Iran \\ 2 Department of Agricultural Market Analysis, Institute of Agricultural Economics, \\ Christian-Albrechts-University Kiel, 24118 Kiel, Germany \\ 3 Leibniz-Institut für Agrartechnik und Bioökonomie e.V. (ATB), Max-Eyth-Allee 100, \\ D-14469 Potsdam, Germany \\ 4 Department of Mechanical \& Biosystems Engineering, Tarbiat Modares University, Tehran 14115-336, Iran \\ 5 Office of the Pro Vice-Chancellor, Federation University, Ballarat, VIC 3350, Australia \\ 6 Department of Mechanical and Electrical Engineering, University of Southern Queensland, \\ Toowoomba, QLD 4350, Australia \\ * Correspondence: samortazavi@modares.ac.ir
}

Received: 28 April 2019; Accepted: 1 July 2019; Published: 11 July 2019

check for updates

\begin{abstract}
As with other regions of Iran, due to excessive extraction of groundwater for intense agricultural activity, Ghorveh plain, a water-scarce irrigation district in the west of Iran, has faced a serious water crisis during the last decade. The present study investigates the impacts of two scenario policies, namely, non-price policy (as a supply-oriented policy) and water pricing policies (as a demand-oriented policy) on agricultural sector of Ghorveh Plain, using positive mathematical programming (PMP). The model was calibrated by using farm-level data for the crop years in 2016-2017. Our findings indicate that applying water supply constraint policy will change the land use and cropping pattern to the crops with higher water productivity. The increase of water resource constraints can lead to the increase of water economic return which indicates a rising value of water resources shortage, warning the producers of the agriculture sector to allocate water to the crops with higher economic value under the water resources shortage conditions. In addition, the findings underline that in a situation where the price of irrigation water is low due to the low elasticity of water demand in the agriculture sector, formulating the economic instruments such as rising water prices does not solely suffice to achieve sustainable water resource management. However, mixed scenarios emphasized that the water distribution policies should be aligned with the increases in water cost.
\end{abstract}

Keywords: positive mathematical programming; agricultural policy; groundwater; pricing

\section{Introduction}

Iran is amongst the most drought stricken countries in the world, in which the rainfall is one-third of the world's average [1]. There are strong indications that Iran is experiencing a severe water crisis which further have been exacerbated by recent high population growth rates, in addition to mismanagement of agricultural irrigation water resources [2,3]. The Iranian agricultural sector, characterized by poor economic efficiency, which is less than 35\% [4] and has outdated irrigation systems, is subject to the current water crisis [1,5]. Irrigated agriculture is responsible to use the lion's share of renewable water resources in Iran [6]. Thus, the most important challenge of the sector is how 
to produce more food with less water [6]. Increasing economic water productivity is among the top priorities for the Iranian policymakers in the agricultural sector [3,5]. Additionally, the implemented policies on food security and the illusion of rapid economic growth have resulted in irregular use of water resources in agriculture [7,8]. "Iran is, indeed, suffering from a socio-economic drought caused by aggressive development which has resulted in water demand being far greater than the available water supply of the country, i.e., a state of water bankruptcy" [1]. The increased gap between the supply and demand of water has inevitably attracted the attention of policymakers to the demand-oriented scheme which was not a significant policy for Iranian officials until recently [3,9]. In response to the current water crisis, the Iranian officials have recently emphasized the goal of water-conservation and water productivity as the binding obligations for the national water resource plans $[5,10]$. Hence, opting for solutions for optimizing water consumption, particularly in water shortage and drought conditions, has a great part to play.

In the context of policy-making, many efforts have been made to reduce water consumption in the agriculture sector and improve its supply amongst various activities. Most of the proposed policies assisting this issue are, directly or indirectly, related to water pricing policy [11] and the reduction of available water. These policies are of substantial significance in terms of policy making and the planning of water resources, as well as demand management [12]. Optimum demand management through pricing can develop the economic role of water focusing on financial requirements of the water sector, and improve the productivity of agricultural crops [13]. Added to the pricing policy of water, water irrigation quotas are considered as another solution or preventing the irregular use of water in the agricultural sector. This policy is possible to be practiced through reducing the volume of irrigated water [14].

One of the most important agricultural production institutions, which benefits from high subsidies inside Iran, is the energy supply, including electricity and fossil fuels (diesel). The statistical analysis showed that in the whole country, the agricultural sector is the third largest electricity consumer after the domestic and industrial sectors. Despite the implementation of the policy of electrifying agricultural wells, this sector is still the largest consumer of gasoline in the country after transportation. With regards to the above-mentioned points, over the past decades, subsidies to agricultural water have led to a reduction in water consumption in this sector, which, on the one hand, has led to excessive consumption of water and, on the other hand, has also caused the government heavy costs.

Due to the fact that the main source of water supply in the studied area (Ghorveh plain) is from groundwater resources (above $80 \%$ ) and water harvesting from these sources will be performed via pumping, this requires an energy supply. In other words, water consumption is directly related to energy consumption and, as a result, avoiding waste water reduces energy consumption. On the other hand, considering its significance, the implementation of pricing and non-pricing water policies reduces water consumption, which in turn can reduce energy consumption for underground water harvesting and extraction. Also, the results of the implementation of these policies and with the decrease in the water supply, farmers' willingness to use new irrigation systems will be further increased, and this idea can eventuate energy consumption.

The growing problems related to the water sector in most parts of the world and the necessity of drawing attention toward the research on pricing and water pricing correction have led to the fact that different studies have been carried out in this regard. References [15-17] do not believe that water price increase policy results in lower water consumption. The fact is that water consumption is allocated to the crops with higher production value, and researchers [18-21] argue that increased agriculture water price results in reduced demand of water by the farmers, thus saving water consumption. Reference [22] believe that incorporating the available water reduction policies and increasing the water price result in a reduction of the irrigated water consumption level. Considering the smallholder farmer of South Africa, Reference [23] showed that water demand is sensitive to minor changes in water price. Implementing a deficit irrigation strategy in the Ghazvin plain resulted in an increase of farm income and a saving of water consumption [24]; however, such a finding was not confirmed 
by [25,26]. According to [27], agricultural irrigation water price is determined based on macro scales (i.e., water price for the whole agricultural activity in the case study) and on micro scales (i.e., for different crops and surface/groundwater resources). Studies conducted by [28-33] are the ones related to the field of agriculture water demand management policies.

Ghorveh plain offers an interesting case to investigate groundwater resource management due to several reasons. First, and most importantly, this plain is one of the most important poles of agriculture in the Kurdistan province. However, the occurrence of recent frequent droughts and an imbalance between supply and demand have had damaging effects on the water resources of the region, particularly in the groundwater resources. Moreover, the main source of water resource in this case study is the groundwater (more than 80\%) [34]. Thus, a growing trend of extracting groundwater in the case study may lead to a serious crisis for whole region, specifically for the agricultural sector. However, it is surprising that the literature on water resource management in regards to this plain is scarce. Consequently, the present study aims at investigating the effects of pricing and non-pricing policies as a practical solution for resolving the water issue, improving water resource productivity and food security in the Ghorveh plain. To this end, two scenario policies, non-pricing (supply-oriented) and pricing (demand-oriented) water scenarios, were identified and formulated by using positive mathematical programming (PMP). It is expected that the obtained results offer solutions for the optimum use of the groundwater resources, preventing the destruction of these resources, and increasing food security.

The paper is organized in four sections. The first section is concerned with an introduction to the area examined in the current study. The second section deals with descriptions of the model and methods used for analysis. The third section discusses the results obtained from the farm-level model and policy scenarios. The fourth section summarizes the findings and provides the conclusions.

\section{Materials and Methods}

\subsection{General Descriptions of the Case Study}

Ghorveh plain, known as one of the semi-drought regions and one of the productive plains in the west of Iran, plays a vital role in economy of agricultural sector of Kurdistan province [35]. The region has an average temperature of $10-13^{\circ} \mathrm{C}$, an average evaporation of $2000-2200 \mathrm{~mm}$, and an average annual rainfall of $348 \mathrm{~mm}$ as well as 78 rainy days [36]. The area of the Ghorveh catchment is about $1063 \mathrm{~km}^{2}$ and the area of the plain is $245 \mathrm{~km}^{2}$. The aquifer of Ghorveh plain is located in the south of the catchment. Figure 1 illustrates the location of Ghorveh plain.

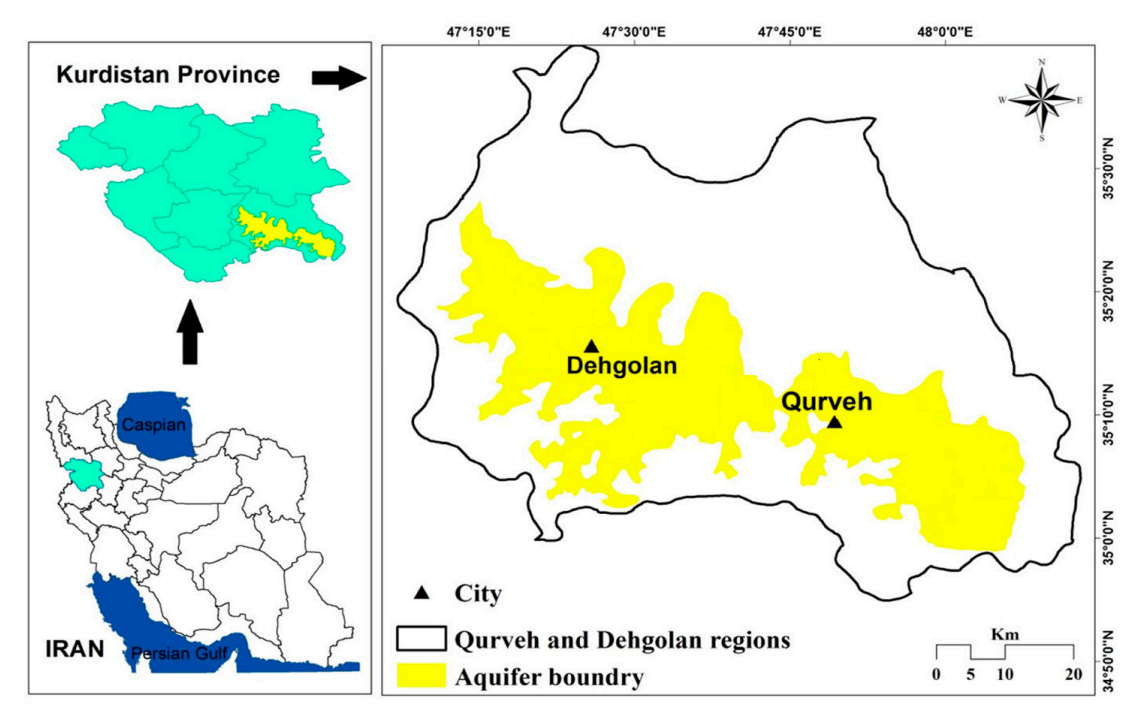

Figure 1. Geological map of the affected area (Adapted with permission from [37]). 
Since aquifer is the main resource of the groundwater in the current case study, the aforementioned plain plays an important role in the agricultural sector of the case study [36]. Due to a significant reduction in the aquifer level since 1993, the plain has faced a serious crisis in a way that it is identified as a forbidden region. Despite the implementation of this policy, the statistics show the continuous trend of reduction in groundwater level [36]. Considering the negative groundwater balance of the plain and the irregular use of the groundwater in Ghorveh plain, it is essential to opt for policies which manage excessive groundwater extractions and lead to the modification of previous trends. In Table 1 is shown information on the status of the water resources of the area.

Table 1. The status of groundwater resources (wells, springs and qanats) and consumption (drinking, agriculture and industry) in the studied area. Data from Iran Water Resources Management Company, [34].

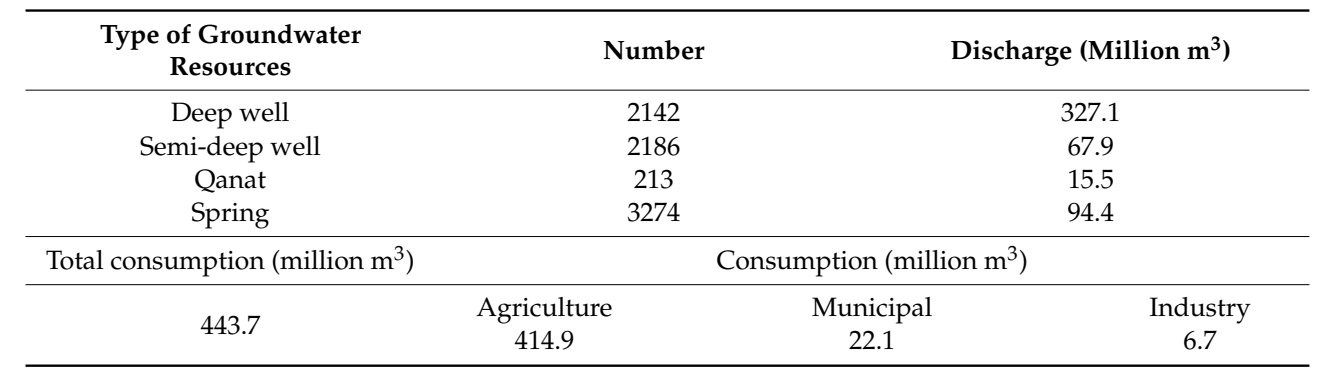

\subsection{Positive Mathematical Programming}

One of the goals of policy makers and planners of agriculture section is to acknowledge the results of implementing various policies and farmers' reactions towards it. Thus, attempting to follow models through the use of this can help achieve this goal. In recent years, different economic models have been proposed to resolve the issues dealing with agriculture section. PMP is one of the models used for the analysis of policies and problem-solving on the coherent level [38]. The model was first suggested by [39]. The structure of this model has been set in a way that evaluation of probable changes effects in market conditions, analyzing agriculture policies concerning the cultivation patterns of farmers, water consumption and the examination of economic repercussions of policies take place based on the goal functions and all constraints involved [22,40-43]. The main concentration of developing such models is to increase the level of confidentiality through avoiding the difference between the current base position and the simulation base position as well as reconsidering the behavior of farmers in their special context based on the quantitative data which exists in the decision-making process of land (the use of land and level of production) [17]. PMP is acknowledged as a common method for analyzing the policies employed [44-48]. The PMP approach is employed for analyzing the proposed scenario policies in this study using Generalized Algebraic Modeling System (GAMS) [49] software package in three stages $[44,49,50]$.

In the first step, a normal linear programming model is developed with a farmers' profit-maximizing function, calibration constraint (observed level of products in the base year), and constraints on resources with an aim to assess the shadow prices of the products under cultivation [51].

$$
\begin{aligned}
& \text { Maximise } Z=p^{\prime} x-c^{\prime} x \\
& \text { Subject to } A x \leq b \quad[\lambda] \\
& x \leq x^{0}+\varepsilon \quad[\rho] \\
& x \geq 0
\end{aligned}
$$

In the LP model (1), where:

$Z=$ objective function value;

$p=$ an $(\mathrm{n} \times 1)$ vector of output prices; 
$c=$ an $(\mathrm{n} \times 1)$ vector of accounting costs per unit of activity;

$x=$ an $(\mathrm{n} \times 1)$ vector of primal variables that are defined as land area allocated to each crop production;

$A=$ an $(\mathrm{m} \times \mathrm{n})$ matrix of input/output coefficients in resource constraints;

$b=$ an $(\mathrm{m} \times 1)$ vector of resource constraints;

$\lambda=$ an $(\mathrm{m} \times 1)$ vector of dual variables associated with the resource constraint;

$\rho=$ an $(\mathrm{n} \times 1)$ dual variables associated with the calibration constrains;

$x^{0}=$ an $(\mathrm{n} \times 1)$ vector of observed primal variables;

$\varepsilon=$ an $(\mathrm{n} \times 1)$ vector of small positive numbers.

The vector $\mathbf{x}$ can be divided into two subsets; a vector of preferred activities $x^{p}$, which is constrained by the calibration constraint and a vector $x^{m}$ of marginal activities which is bounded by the resource constraint. Assuming that all components of $x^{0}$ are nonzero and all constraints resources are obligatory, i.e., all resources are used. Kuhn-Tucker conditions explicitly implies that [52].

$$
\begin{aligned}
& \rho^{p}=p^{p}-c^{p}-A^{p} . \lambda \\
& \rho^{p}=0 \\
& \lambda=\left(A^{\prime m}\right)^{-1}\left(p^{m}-c^{m}\right),
\end{aligned}
$$

where dual values of calibration constraints $(\rho)$ are zero and equal to the difference between marginal cost and prices for $\left(p^{m}\right)$ marginal activities and $\left(p^{p}\right)$ preferable activities, respectively. The marginal cost involves the variable costs per activity unit $\left(c^{p}\right)$ and marginal cost of employed fixed resources $\left(A^{p} . \lambda\right)[53]$.

In the second step, the results obtained from the shadow price for the first step are used to evaluate non-linear object functions parameters so that the observed activity levels are reproduced in the base period using the afore-mentioned non-linear programming and without the use of calibration constraints [41,45]. Every non-linear function with the required characteristic can be employed at this step. The multi-product variable cost function with quadratic function was used in his study as shown in Equation (3) [54]. There are two approaches to (estimate) calibrate a non-linear objective in PMP, either using a non-linear cost function or a non-linear yield function. Due to the duality between the cost function and the underlying production technology [55], the results of these two approaches are the same [48]. However, from a calculation viewpoint, cost function is more straightforward to formulate and easy to calculate. Cost function is more suitable to simulate our proposed policy scenarios (price policies).

$$
C^{v}(x)=d^{\prime} x+\frac{1}{2} x^{\prime} Q x
$$

with:

$d=$ an $(n \times 1)$ vector of linear cost coefficients to be calibrate

$Q=$ an $(n \times n)$ symmetric and positive semi-definite of parameters associated with the quadratic cost coefficients

In Equation (3), vector $d$ and matrix $\hat{Q}$ represent all calibrated parameters of the non-linear object function. In addition, the ultimate cost vector of $\left(M C^{V}\right)$ variable dealing with the cost function equals to the sum of accounting cost vector $(\mathrm{C})$ and differential final margin vector.

$$
M C^{V}=\nabla C^{v}(x)_{x 0}^{\prime}=d+Q x_{0}=c+\rho .
$$

In the third step, the estimated non-linear cost function at the second step is used in the object function of the considered problem, and the non-linear object function is used in non-linear planning 
problem similar to the first problem except for the calibration constraint along with corresponding systematic constraints. The following PMP model was obtained for the simulation:

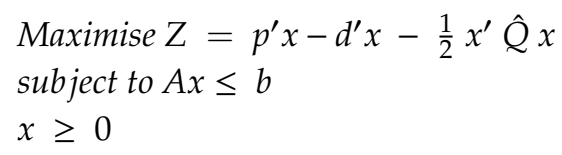

For the moment, the calibrated non-linear programming reproduces observed activities levels in the base year and dual values with resource constraints, and it would be useful in simulating the changes in optimum parameters [39]. We either can use CES or quadratic cost function to calibrate our model [45]. However, the quadratic cost function is more flexible to run the model [39]. The main goal is to simulate policy to find a feasible solution mathematically. The real issue, in reality, is more complex, and we have to assume some constraint in the modelling. This is a general characteristic of farm-level modeling. According to the research topic and its goals, the limitations of the present study involve groundwater resources, land, labor force, machines, chemical fertilizers (nitrogen and phosphate), and a chemical (fungicides, herbicides, and insecticides) uses constraint. It is worth noting that the PMP model highlights the changes dealing with the aforementioned productive factors with regards to various policies. Due to the importance of water shortage in the area under cultivation, the changes of these two fundamental factors have been reported in the current study.

The statistics and information required for conducting the calculations and estimation of the model were obtained from the relevant organizations and departments such as Kurdistan Agricultural Organization, Kurdistan Regional Water Authority, Water Resources Affairs, and Ministry of Energy for the crop year 2016-2017. Moreover, the model is developed in General Algebraic Modeling System (GAMS) version 24.1.2 (developed by GAMS Development Corporation, USA, VA) using the CONOPT solver.

\section{Results and Discussion}

In this section, the results obtained from the agro-economic model are initially discussed, then, the effects of choosing water-conservative policies on the crop mix, groundwater extraction and farm income are represented. As laid out above, we applied an agro-economic PMP-based model to determine the optimum crop mix. The model results have been shown in Table 2. As shown, the proposed model has been able to reproduce the base year information accurately, which confirms the validity of the model.

Table 2. Comparison of under cultivation area of base model and results of calibrated positive mathematical programming (PMP) model solution.

\begin{tabular}{ccc}
\hline Crop & Baseline (Hectare) & Results of PMP Solution \\
\hline Wheat & 12,100 & $12,101.1$ \\
Barley & 1216.1 & 1216 \\
Alfalfa & 3560.4 & 3560.7 \\
Potato & 4366.6 & 4366 \\
Cucumber & 1402 & 1402 \\
Clover & 399.5 & 398.6 \\
Onobrychis & 350.7 & 350.1 \\
\hline
\end{tabular}

\subsection{The Basis for Defining Policies}

Nowadays, the policy-based plans or management solutions dealing with the stability and preserving of the water resources in most of the drought areas of the world are used. Regarding the fact that groundwater cost condition as a policy-based instrument can have an influential role on controlling the exploitation of the groundwater resources, different costs were determined per square and its effect on some of the economic and agricultural parameters of the region was studied. It is 
worth pointing out that water pricing in Ghorveh plain is zero. In this study, the existing scenarios were considered based on the shadow price obtained from the model. The water intake shadow price in the PMP model was obtained as 3091 Rials (0.09\$) (1 US Dollars equals 34,211 Iranian Rial). In the second stage, 10 percent of the water shadow cost was considered as the water pricing paid by the farmers. Thus, the water cost per square of consumption was determined as 309 Rials $(0.009 \$), 618$ Rials $(0.018 \$)$, and 927 Rials $(0.027 \$)$ after implementing $10 \%, 20 \%$, and $30 \%$ scenarios, respectively. Also, the consumption costs were considered in the model.

Considering the precipitation conditions of the following year and the probability of drought expansion as well as the necessity for preserving the water resources in long-term, it was attempted in this study to include and examine $10 \%, 20 \%$, and $30 \%$ scenarios for the expressed policies.

One of the direct policies influencing the water resources is the quota of the water taken from the wells which is considered under the reduction of groundwater use scenario so as to examine its effects in the considered area. These scenarios include: Scenario 4 (SE4): 10\% reduction in groundwater use, Scenario 5 (SE5): 20\% reduction in groundwater use and Scenario 6 (SE6): 30\% reduction in groundwater use.

Also, according to the country's goals and strategies for preserving and sustaining water resources, three other scenarios for simultaneous changes related to the reduction of groundwater use and its price increase have been considered in order to examine its effects in the studied area.

(SE7): A combination of a $10 \%$ increase in water price and $10 \%$ reduction in groundwater available;

(SE8): A combination of $20 \%$ increase in water price and $20 \%$ reduction in groundwater available;

(SE9): A combination of 30\% increase in water price and 30\% reduction in groundwater available.

The results would show the effect of irrigation price increase on adoption of deficit irrigation. Also, the results would represent the farmers' reactions toward the condition under which the restriction of water distribution is reduced. Table 3 illustrates the scenarios related to the price change policies, values and policy of price balancing, and quotas of underground water resources which are designed for the agriculture sector.

Table 3. Different policy scenarios of water pricing and water quota in Ghorveh plain.

\begin{tabular}{ccc}
\hline \multicolumn{2}{c}{ Type of Policy } & Scenario \\
\cline { 1 - 2 } Water Quota & Water Pricing & \\
\hline Current Condition & Current Condition & SE $_{0}$ (Baseline Scenario) \\
No water quota & $10 \%$ Increase & SE1 \\
No water quota & $20 \%$ Increase & SE2 \\
No water quota & $30 \%$ Increase & SE3 \\
$10 \%$ Decrease & No water pricing & SE4 \\
$20 \%$ Decrease & No water pricing & SE5 \\
$30 \%$ Decrease & No water pricing & SE6 \\
$10 \%$ Decrease & $10 \%$ Increase & SE7 \\
$20 \%$ Decrease & $20 \%$ Increase & SE8 \\
$30 \%$ Decrease & $30 \%$ Increase & SE9 \\
\hline
\end{tabular}

\subsection{Results of the Policies Simulations}

This section provides the results concerning the evaluation of the PMP model and simulation of different scenarios for Ghorveh plain. Figure 2 shows the results related to cropping pattern changes and consumed water level per the changes of groundwater cost in Ghorveh plain. As the table shows, the increase of groundwater cost in all scenarios of water pricing, land use of potato and alfalfa crops increases compared to the base year while the land use of wheat, barley, and cucumber reduces compared to the base year. Experiencing the increase in water cost, farmers endeavor to maintain and preserve the crops which are economically profitable compared to other cops per water square. Also, they attempt to reduce land use of crops which use higher levels of water and have a lower gross margin. Implementing such a policy did not have any effect on clover and alfalfa crops. One can 
say that the Onobrychis (due to lack of bloating) and Clover are pure feed for livestock, particularly the lactating livestock. On the other hand, these two crops have the lowest land use so that they occupy $3 \%$ of the area lands in terms of cultivation. The increase of groundwater cost has not made considerable changes in this regard. All in all, implementing water pricing policy in the Ghorveh plan increases the tendency of farmers to develop land use of wheat, barley, and cucumber. Also, farmers of this region are encouraged to develop land use of crops such as potato and alfalfa which have high economic profit.

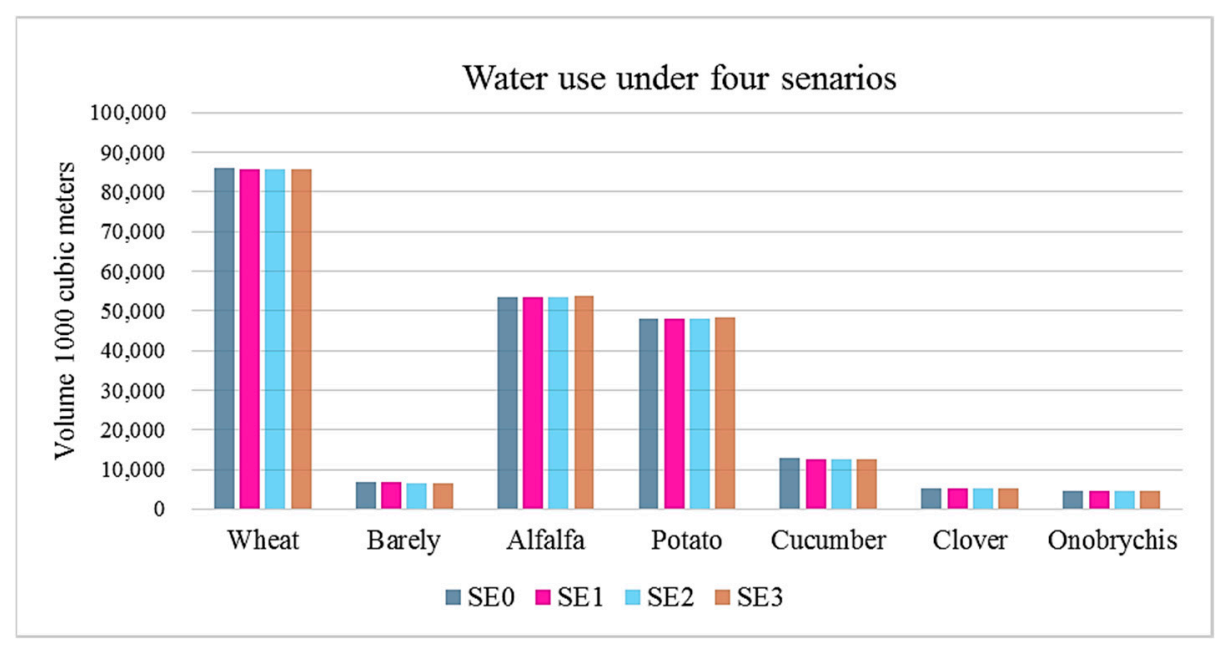

(a)

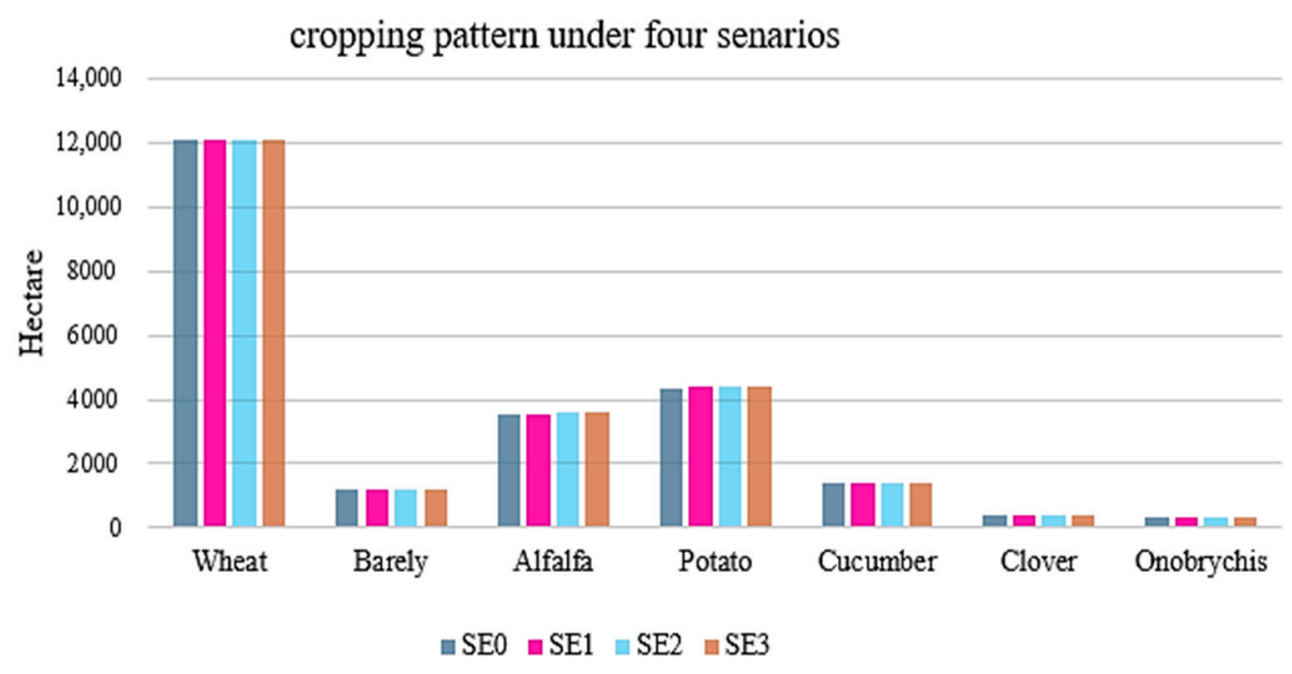

(b)

Figure 2. The effect of groundwater pricing scenarios on (a) consumed water level and (b) cultivation patterns. (See Table A1 for details).

Figure 3 represents the results obtained from implementing the quotas of irrigation water in the Ghorveh plain. After implementing this policy, our findings show that the cultivation pattern of assumed agricultural products changed with respect to the status quo. Cultivated area under potato increased by $3.2 \%, 6.5 \%$, and $7.2 \%$ for $\mathrm{SE}_{4}, \mathrm{SE}_{5}$, and $\mathrm{SE}_{6}$, respectively. The reason for such an increase in land use is the lower water condition need compared to other cultivation pattern products and the higher economic return derived from each hectare compared to other patterns in the studied region. On the other hand, land use of other crops has been reduced so that the farmers show enthusiasm to change the cultivation pattern based on the reduction of available water. Also, the results indicate that 
in water supply limitation conditions, barley, clover and Onobrychis crops enjoy a more sensitive level (the maximum change level) compared to other pattern crops (wheat, alfalfa, and cucumber) which also have the maximum percent of the reduction in land use. One can mention the reason for such a reduction in land use as the fact that these crops have the minimum economic benefit compared to other crop products. Such an affair reflects non-development of land use amongst these crops for the regional farmers in drought crisis conditions.

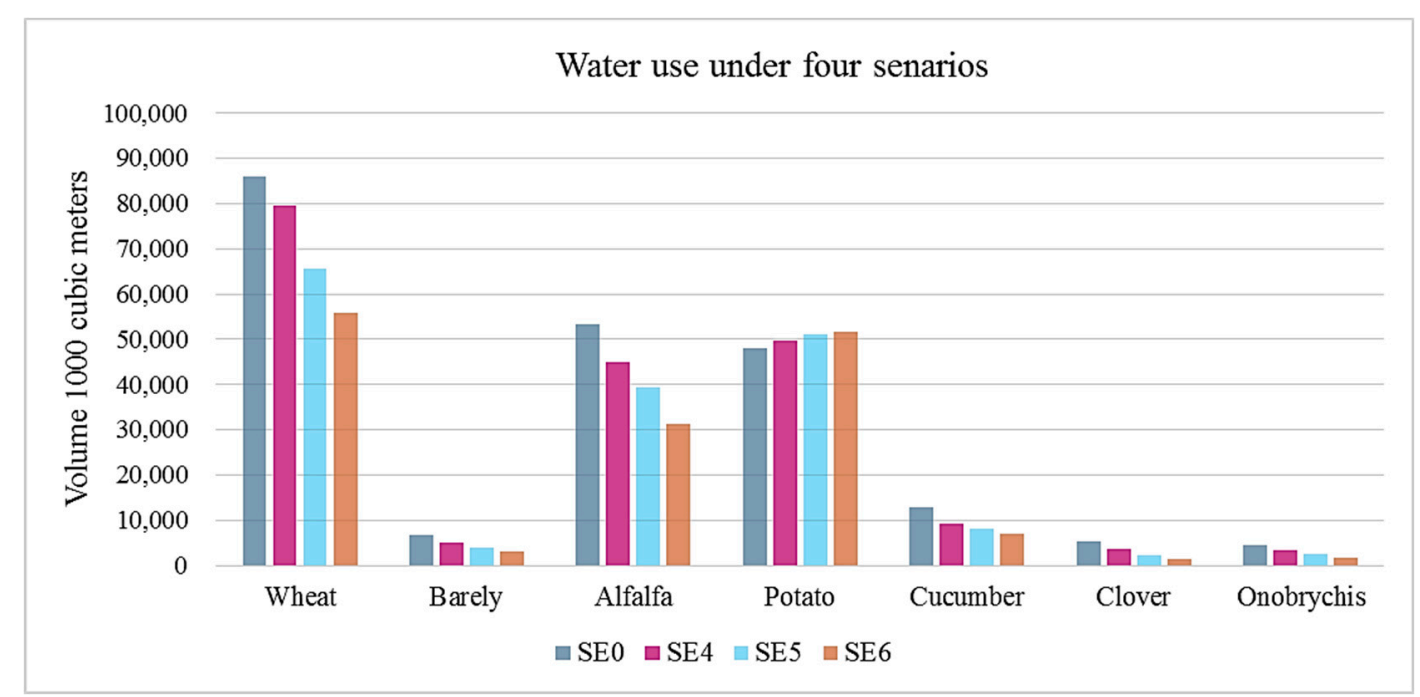

(a)

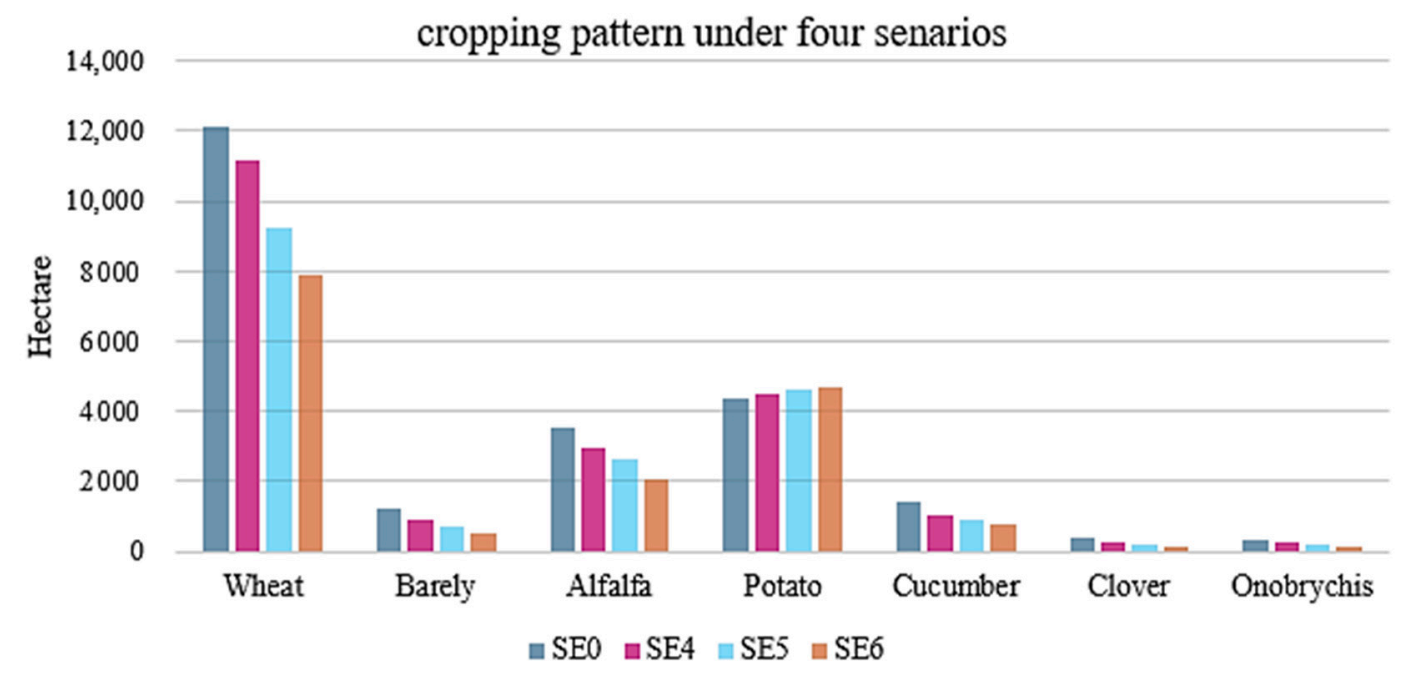

(b)

Figure 3. The effect of groundwater quota scenarios on (a) consumed water level and (b) cultivation pattern. (see Table A2 for details).

Figure 4 shows the results of the third policy, i.e., simultaneous change of exploitation reduction and groundwater cost increase. As the results depict, implementing this type of policy leads to increase in land use of potato so that its changes are lower compared to the aforementioned policy. In contrast, the land use of other crops has decreased. Implementing this policy leads to an increase in the production cost of crops with high levels of water involved. 


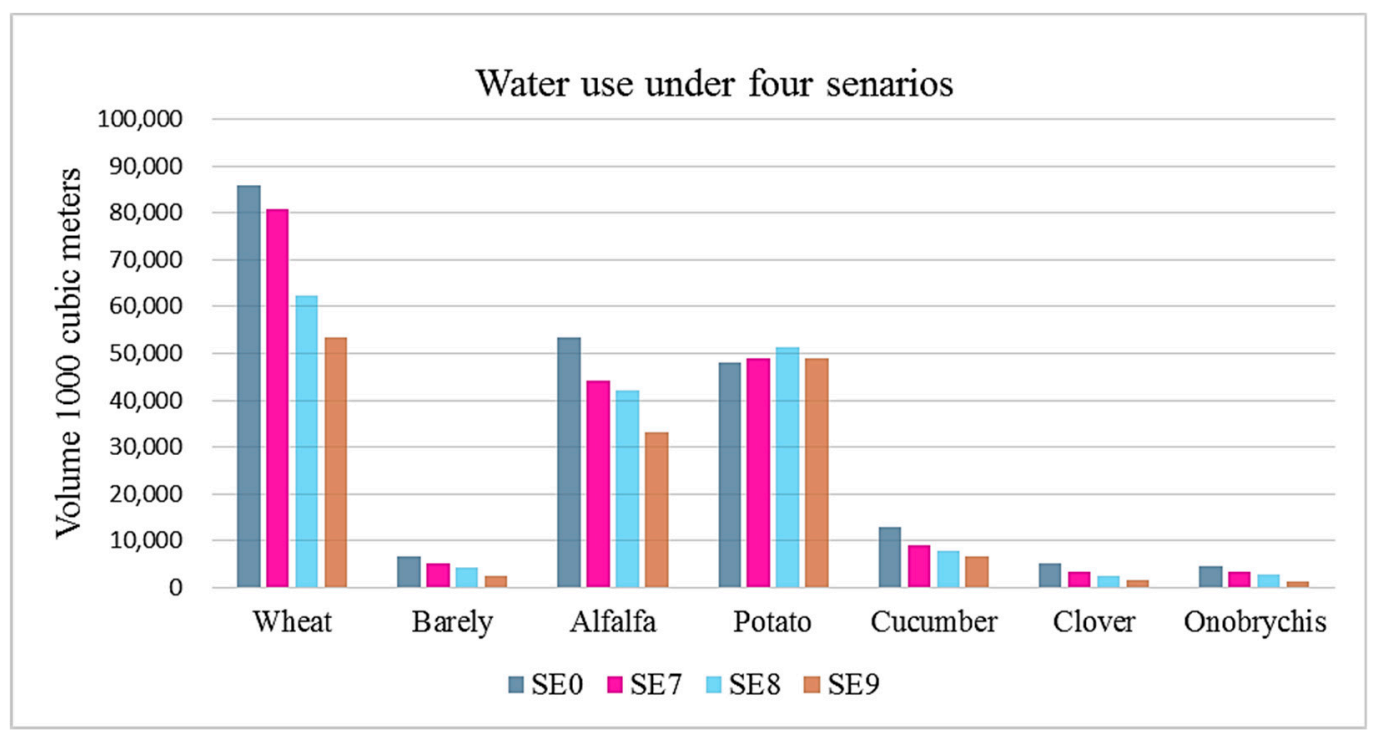

(a)

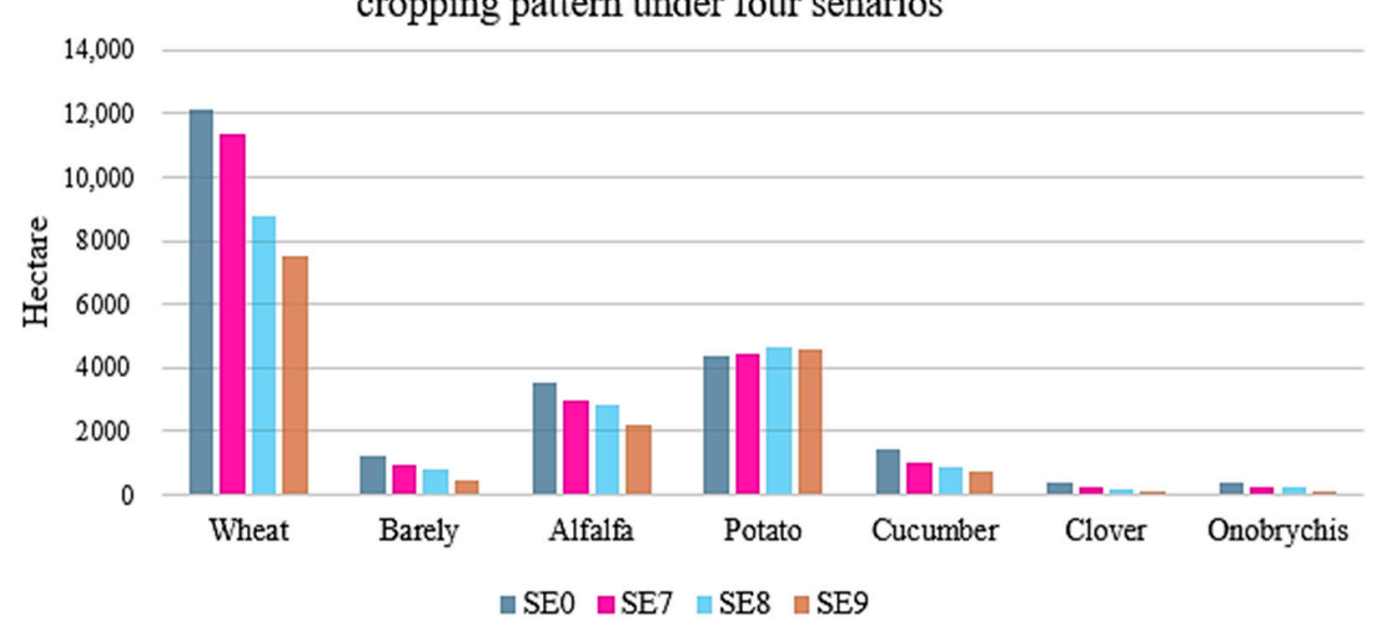

(b)

Figure 4. The results of solving positive mathematical programming model based on simultaneous scenarios of pricing and quota. (a) consumed water level. (b) cultivation pattern. (see Table A3 for details).

In the current study, the effects of pricing policies and reduction of water exploitation, in addition to the input water consumption and land use, on the total gross margin of the region derived from cultivation pattern for farmers and economic return per cubic meter of water were analyzed. Figures 5 and 6 shows the results obtained in this context. 


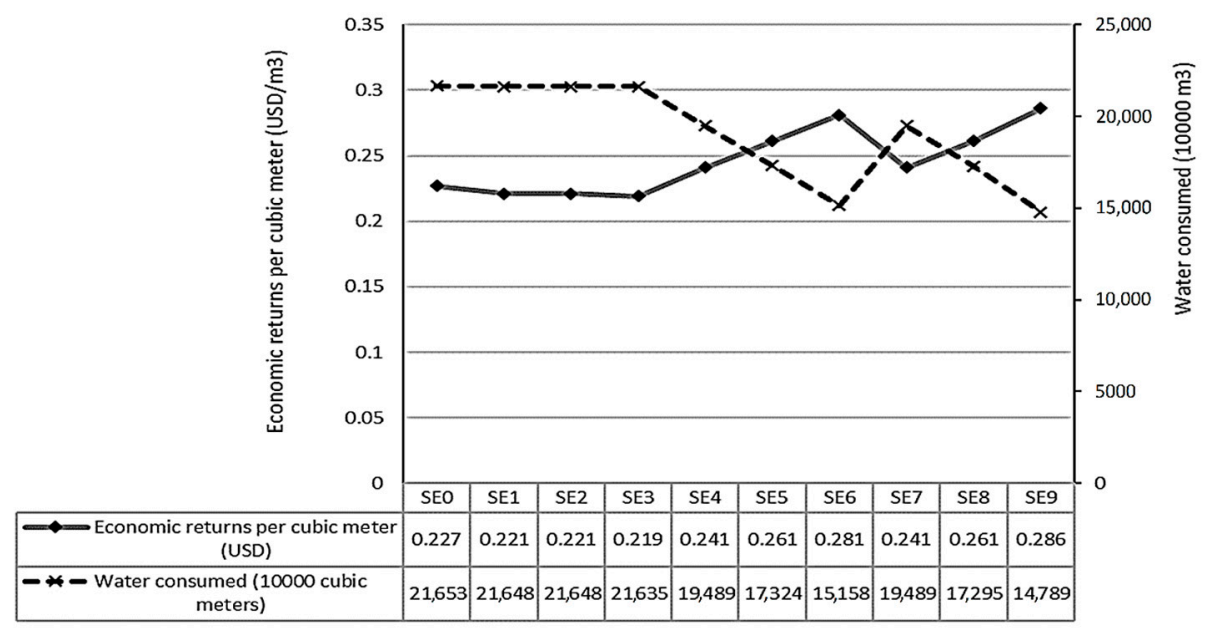

Figure 5. Comparing economic return per water $\left(\mathrm{USD} / \mathrm{m}^{3}\right)$ and water consumption $\left(10,000 \mathrm{~m}^{3}\right)$ under different scenarios.

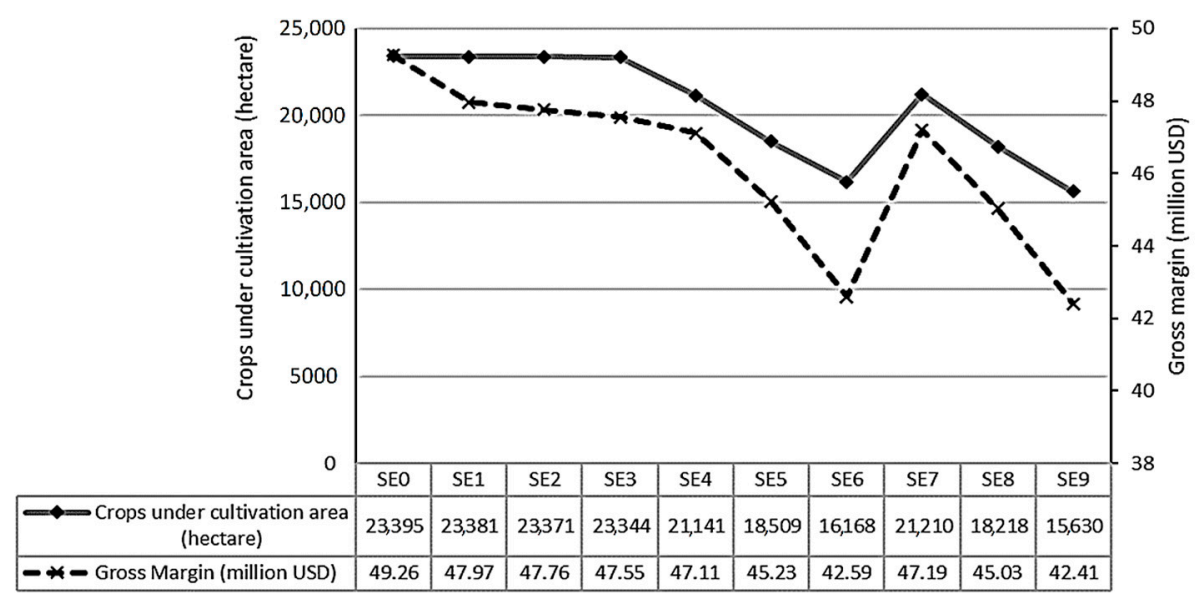

Figure 6. Comparing land use and gross pattern return under different scenarios.

The results of Figures 5 and 6 show that implementing water pricing policy under $10 \%$ to $30 \%$ scenarios is not influential with respect to maintaining and preserving the water resources while increasing the farmer's cost. Despite the reduction in land use of crop products by $0.06 \%$ to $0.2 \%$, a reduction in gross margin by $2.6 \%$ to $3.6 \%$ was obtained. Generally, the implementation of this policy in Ghorveh plain has resulted in farmers' cost increasing and a reduction in the gross margin of the farm, having a lower effect on saving the groundwater resources. The effects of pricing scenarios results are based on the findings reported by $[17,18,28]$. Also, the same policy results in a reduction of economic return per cubic meter of water. As it was stated earlier, the results of water quota policy showed that although the gross margin of farmers was reduced in relation to the existing condition, such a profit was accompanied by saving it using a large portion of input water across the lands. In other words, one can say that the reduction of water consumption results in a reduction of income due to the reduction of performance in crop products and a reduction in land use of crops; however, the reduction percent of profit is less than the reduction percent of crop land use and consumed water level when considering all the scenarios. Implementing such a policy under 10\% to 30\% scenarios results in a reduction of the total land use of crops $(9.3 \%$ to $33.2 \%$ ) and a reduction of pressure on the land. Also, the reduction of water consumption compared to the base year results in a gross margin derived from the cultivation of crop by $4.5 \%$ to $15.6 \%$. The results dealing with implementing groundwater quota policy are in line with the one reported by [22,56-58]. Outcomes of the above-mentioned studies showed that implementing the water quota policy develops the crop cultivation with a lower water requirement along with 
higher economic return per cubic meter of irrigation water. In addition, reduction of groundwater consumption was found to be a suitable solution for preserving and maintaining water resources. Findings of simultaneous reductions in exploitation and water price increasing policy in Scenarios 7 to 9, which were the same as the water quota policy, encouraged farmers to reduce the land use of some crop products in the region (water wheat, water burly, alfalfa, clover, Onobrychis, and cucumbers) while reducing gross margin of crop production. Such a reduction of profit is less than that of the water consumption reduction which was $4.3 \%, 9.4 \%$, and $16.1 \%$ for SE7, SE8, and SE9 scenarios, respectively. Implementing water resources lower consumption policies (water quota and simultaneous integration of price and quantity) leads to significant increase in water economic return. As shown in Figure 5, Scenario SE9, which involves a 30\% simultaneous change of exploitation and water cost increase, has the maximum economic return per consumed water square (9813 Rials per cubic meter). High levels of water economic return represent the value of water shortage so that higher levels of water shortage result in an increased economic value. The results of simultaneous implementation of cost and quantity policy are supported by findings of the studies carried out by [56,59-61] who mentioned that the maximum improvement of groundwater level is achieved when the pricing and quota policies are integrated simultaneously.

In general, the results of Figures 5 and 6 show that simultaneous cost balancing and groundwater quota policy encourage the farmers of Ghorveh city to save water resources. Considering saved water level in the context of implementing simultaneous cost balancing and water resources quota policy, such a policy is much more influential in maintaining and preserving the water resources of Ghorveh when compared to the cost increase of irrigation water policies.

\section{Conclusions}

Considering the inappropriate condition of groundwater exploitation resources and irregular use of such a valuable resource, the water height in this plain has decreased significantly and endangered groundwater resource savings. Continuation of such a trend puts the economy of the region at risk which is based on agriculture which also brings about problems in providing industrial water and drinkable water. Therefore, the significance of studies undertaken in this regard is clear and evident. It was attempted in this study to examine the effects dealing with groundwater consumption reduction policies within a positive mathematical programming on economic components such as the income derived from producing input water return, regional cultivation pattern and water consumption level considering groundwater resources, and to offer solutions in order to consume groundwater resources optimally and prevent depletion of these resources. To solve the model, data related to crop years of 2016-2017 and GAMS software were used.

Outcomes of the present study indicated that implementing water quota policies (direct policy), increasing water cost (indirect policy) and simultaneous effects of these policies lead to a reduction in water consumption, reduction in land use and a reduction of gross margin in the region. The results of the water cost increasing policy indicated that such a policy did not have a significant effect and increased only the cost of farmers. Its effectiveness was guaranteed in case complementary non-cost policies are decided. Also, in all scenarios of water quota and simultaneous integration of cost and quantity $(10 \%, 20 \%$, and $30 \%)$, the land use was reduced by the reduction of available water, and the cultivation pattern proceeded in benefiting the products which offer more income per cubic meter of water. The point is that the implementation of these policies does not necessarily lead to crops with lower water requirement in cultivation pattern; rather, economic variables and level of return dealing with crops are considered as important factors in this regard. Farmers are able to leave parts of their land uncultivated, but they do not tend to add low-efficient crops with less water requirement. Another important point is that although the reduction of gross margin derived from agricultural crops as a result of a reduction in the water supply is inevitable, such a reduction is less than the area under cultivation and reduction of water distribution level in case the proper economic cropping pattern is observed. Generally speaking, it is possible to say that simultaneous reduction of cost and quantity 
policy is much more optimal than the water quotas policy. Implementing these policies resulted in preserving and preventing the groundwater resources as well as the under cultivation area, and the economic return per cubic meter of water was found to be higher than the other scenarios.

Based on the results above, following polices are suggested to be considered with an aim to improve the groundwater resources of Ghorveh plain: Development and continuous exploitation control of water resources through installing smart meters on all deep and semi-deep wells, preventing all illegal exploitation and blocking unauthorized wells in the studied area, and preventing overuse of authorized wells. All of these methods can assist the preserving of groundwater resources of Ghorveh plain.

Author Contributions: Conceptualization (M.A.A., S.A.M., O.Z.), modelling (M.A.A and O.Z.), original draft preparation (M.A.A., S.A.M., O.Z.), review and editing (G.H.N., T.Y., S.S.H.).

Funding: The authors are grateful to the Tarbiat Modares University (TMU) for financial supports given under IG/39705 grant for renewable Energies of Modares research group.

Conflicts of Interest: The authors declare no conflict of interest.

\section{Appendix A}

The Effects of Scenarios in Detail.

Table A1. The effect of groundwater pricing scenarios on cropping patterns and consumed water level.

\begin{tabular}{|c|c|c|c|c|c|c|c|c|}
\hline \multirow[t]{2}{*}{ Crops } & \multicolumn{4}{|c|}{ Cropping Pattern (Hectare) } & \multicolumn{4}{|c|}{$\begin{array}{c}\text { Water Consumption Level (1000 Cubic } \\
\text { Meters) }\end{array}$} \\
\hline & SE0 & SE1 & SE2 & SE3 & SE0 & SE1 & SE2 & SE3 \\
\hline Wheat & $12,101.1$ & 12,094 & 12,087 & $12,060.6$ & $85,917.81$ & $85,867.4$ & $85,817.7$ & $85,630.26$ \\
\hline Barely & 1216 & 1210.4 & 1204.7 & 1202 & 6688 & 6657.2 & 6626.85 & 6611 \\
\hline Alfalfa & 3560.7 & 3564.7 & 3570.2 & 3577.5 & $53,410.5$ & $53,470.5$ & 53,553 & $53,662.5$ \\
\hline Potato & 4366 & 4371.2 & 4377.9 & 4383.7 & 48,026 & $48,083.2$ & $48,156.9$ & $48,220.7$ \\
\hline Cucumber & 1402 & 1390.5 & 1379 & 1367.5 & $12,758.2$ & $12,653.55$ & $12,548.9$ & $12,444.25$ \\
\hline Clover & 398.6 & 400 & 400.5 & 401 & 5181.8 & 5200 & 5206.5 & 5213 \\
\hline Onobrychis & 350.1 & 350.1 & 351.3 & 351.6 & 4551.3 & 4551.3 & 4566.9 & 4570.8 \\
\hline
\end{tabular}

Table A2. The effect of groundwater quota scenarios on cropping pattern and consumed water level.

\begin{tabular}{|c|c|c|c|c|c|c|c|c|}
\hline \multirow[t]{2}{*}{ Crops } & \multicolumn{4}{|c|}{ Cropping Pattern (Hectare) } & \multicolumn{4}{|c|}{$\begin{array}{l}\text { Water Consumption Level (1000 Cubic } \\
\text { Meters) }\end{array}$} \\
\hline & SE0 & SE4 & SE5 & SE6 & SE0 & SE4 & SE5 & SE6 \\
\hline Wheat & $12,101.1$ & $11,187.8$ & 9252 & 7859.3 & $85,917.81$ & $79,433.38$ & $65,689.2$ & $55,801.03$ \\
\hline Barely & 1216 & 928.9 & 707.4 & 537.1 & 6688 & 5108.95 & 3890.7 & 2954.05 \\
\hline Alfalfa & 3560.7 & 2989.6 & 2632.7 & 2077.1 & $53,410.5$ & 44,844 & $39,490.5$ & $31,156.5$ \\
\hline Potato & 4366 & 4504.37 & 4650.2 & 4681.5 & 48026 & $49,548.07$ & $51,152.2$ & $51,496.5$ \\
\hline Cucumber & 1402 & 1009.5 & 884.4 & 768.5 & $12,758.2$ & 9186.45 & 8045.31 & 6993.35 \\
\hline Clover & 398.6 & 268.7 & 181.2 & 114.7 & 5181.8 & 3493.1 & 2355.6 & 1491.1 \\
\hline Onobrychis & 350.1 & 252.3 & 201.3 & 130.1 & 4551.3 & 3279.6 & 2616.9 & 1691.3 \\
\hline
\end{tabular}


Table A3. Results of solving PMP model based on simultaneous scenarios of pricing and quotas.

\begin{tabular}{|c|c|c|c|c|c|c|c|c|}
\hline \multirow[t]{2}{*}{ Crops } & \multicolumn{4}{|c|}{ Cropping Pattern (Hectare) } & \multicolumn{4}{|c|}{$\begin{array}{l}\text { Water Consumption Level (1000 Cubic } \\
\text { Meters) }\end{array}$} \\
\hline & SE0 & SE7 & SE8 & SE9 & SE0 & SE7 & SE8 & SE9 \\
\hline Wheat & $12,101.1$ & $11,370.6$ & 8780.7 & 7525.4 & $85,917.81$ & $80,731.26$ & $62,342.97$ & $53,430.34$ \\
\hline Barely & 1216 & 911.6 & 776.6 & 472 & 6688 & 5013.8 & 4271.3 & 2596 \\
\hline Alfalfa & 3560.7 & 2939.2 & 2802.5 & 2211.6 & $53,410.5$ & 44,088 & $42,037.5$ & 33,174 \\
\hline Potato & 4366 & 4452.3 & 4654.2 & 4553.3 & 48,026 & $48,975.3$ & $51,196.2$ & $48,986.3$ \\
\hline Cucumber & 1402 & 995.7 & 865.2 & 737.7 & $12,758.2$ & 9060.87 & 7873.32 & 6713.07 \\
\hline Clover & 398.6 & 270.7 & 191.7 & 121.5 & 5181.8 & 3519.1 & 2492.1 & 1579.5 \\
\hline Onobrychis & 350.1 & 269.6 & 210.4 & 108.2 & 4551.3 & 3504.8 & 2735.2 & 1406.6 \\
\hline
\end{tabular}

\section{References}

1. Madani, K.; Agha-Kouchak, A.; Mirchi, A. Iran's Socio-Economic Drought: Challenges of a Water Bankrupt Nation. Iran Stud. 2016, 49, 997-1016. [CrossRef]

2. Zobeidi, T.; Yazdanpanah, M.; Forouzani, M.; Khosravipour, B. Climate Change Discourse among Iranian Farmers. Clim. Chang. 2016, 138, 521-535. [CrossRef]

3. Boazar, M.; Yazdanpanah, M.; Abdeshahi, A. Response to water crisis: How do Iranian Farmers Think about and Intent in Relation to Switching from Rice to Less Water Dependent Crops? J. Hydrol. 2019, 570, 523-530. [CrossRef]

4. Abbasi, F.; Heydari, N.; Sohrab, F. Water Use Efficiency in Iran Islamic Republic: Status, Challenges and Opportunities. In AARINENA Water Use Efficiency Network, Proceedings of the Expert Consultation Meeting, Aleppo, Syria, 26-27 November 2006; Hamdan, I., Oweis, T., Hamdallah, G., Eds.; AARINENA: Tehran, Iran, 2006; pp. 58-70.

5. Madani, K. Water Management in Iran: What is Causing the Looming Crisis? Environ. Stud. Sci. 2014, 4, 315-328. [CrossRef]

6. Nazari, B.; Liaghat, A.M.; Akbari, M.R.; Keshavarz, M. Irrigation water management in Iran: Implications for water use efficiency improvement. Agric. Water Manag. 2018, 208, 7-18. [CrossRef]

7. Lalehzari, R.; Tabatabaei, S.H. Simulating the Impact of Subsurface Dam Construction on the Change of Nitrate Distribution. Environ. Earth Sci. 2015, 74, 3241-3249. [CrossRef]

8. Lalehzari, R.; Tabatabaei, S.H.; Kholghi, M. Simulation of Nitrate Transport and Wastewater Seepage in Groundwater flow System. Int. J. Environ. Sci. Technol. 2013, 10, 1367-1376. [CrossRef]

9. Zamani, O.; Grundmann, P.; Libra, L.A.; Nikouei, A. Limiting and Timing Water Supply for Agricultural Production-The Case of the Zayandeh-Rud River Basin, Iran. Agric. Water Manag. 2019, 222, 322-335. [CrossRef]

10. Entekhab. New York Times Report of Water Crisis in Iran: Half of the Country Dry. Available online: https://www.entekhab.ir/ (accessed on 19 October 2018).

11. Reddy, V. Water Pricing as a Demand Management Option: Potentials, Problems and Prospects; Maria Saleth, R., Ed.; Water Sector Perspective Plan for India: Potential Contributions from Demand Management in Irrigation. Strategic Analysis of National River Linking Project of India; Series 3; International Water Management Institute: Colombo, Sri Lanka, 2009; pp. 25-46.

12. Jalil Piran, H. The Role of Water Pricing in Agriculture on the Balance of Water Resources. Econ. J. 2012, 2, 119-128.

13. Ehsani, M.; Hayati, B.; Dashti, G.H.; Ghahremanzade, M.; Hossenzad, J. Water Economic Value Estimation in Barley Production at Qazvin Plane Irrigation Network. Water Soil Sci. 2012, 2, 187-200.

14. Caii, X.M.; Rosegrant, M.W. Irrigation Technology Choices under Hydrologic Uncertainty: A Case Study from Maipo River Basin, Chile. Water Resour. Res. 2004, 40, 1-10. [CrossRef]

15. Ward Kristen, B. Evaluating Producer Response to Water Policies in Agriculture: The Role of Input Substitution, Spatial Hetrogeneity and Input Quality. Ph.D. Thesis, University of California, Davice, CA, USA, 2003.

16. Sabohi, M.; soltani, G.R.; Zibaei, M. Investigating the Effect of Irrigation Water Prices Changes on Private and Social Benefits using Positive Math Planning. Agric. Sci. Technol. J. 2007, 21, 53-71. 
17. Gharaghani, F.; Boostani, F.; Soltani, G.R. Assessing the Impact of Reducing Irrigation Water and Increasing its Price on Cropping Pattern by Positive Mathematical Programming Model: A Case Study of Eghlid in Fars Province. J. Agric. Econ. Res. 2009, 1, 57-74.

18. Huang, G.H.; Rozelle, S.; Howitt, R.E.; Wang, J. Irrigation Water Demand and Implications for Water Pricing Policy in Rural. China Int. Food Agric. Policy. 2010, 143, 57-79.

19. Balali, H. Effect of Cost and Agricultural Policy on Conservation of Groundwater Resources: A Case Study of Vahar Plain. Ph.D. Thesis, Tarbiat Modares University, Tehran, Iran, 2010.

20. Najafi Alamdarlo, H.; Ahmadian, M.; Khalilian, S. Economic Assessment of Groundwater Pricing Policy in Varamin Plain. J. Agric. Econ. Res. 2013, 5, 137-154.

21. Varziri, A.; Vakilpour, M.; Mortazavi, A. The Effects of Economic Pricing of Irrigation Water on Cropping Pattern in the Dehgolan Plain. J. Agric. Econ. Res. 2016, 31, 81-100.

22. Cortignani, R.; Severini, S. Modeling Farm-Level Adoption of Deficit Irrigation Ysing Positive Mathematical Programming. Agric. Water Manag. 2009, 96, 1785-1791. [CrossRef]

23. Spielman, D.; Ekboir, L.; Davis, J. The Aart and Science of Innovation Systems Inquiry: Applications to SubSaharan African agriculture. Technol. Soc. 2009, 31, 399-405. [CrossRef]

24. Asaadi, M.A. Economic Analysis of Deficit Irrigation Strategies for Managing Agricultural Water Resources (Case Study: Qazvin Plain Irrigation Network). Master's Thesis, Tarbiat Modares University, Tehran, Iran, 2017.

25. Baniasadi, M.; Zare Mehrjerdi, M.; Mirzaei KhalilAbad, H.; Rezaee AHasanvand, M. Study of Cropping Pattern Changes and Groundwater Resources Extraction by Implementing Reduced Water Consumption Policies in Orzuiyeh Plain of Kerman Province. Agric. Econ. 2017, 11, 111-129.

26. Parhizkari, A.; Sabohi, M.; Ahmadpoor, M.; Badizarin, H. Assessment of the Effects of Deficit Irrigation and Decrease in Water Allocation on Agricultural Sector Production in Qazvin Province. J. Water Res. Agric. 2016, 6, 173-185.

27. Ren, Y.; Wei, S.; Cheng, K.; Fu, Q. Valuation and Pricing of Agricultural Irrigation Water Based on Macro and Micro Scales. Water 2018, 10, 1044. [CrossRef]

28. Lómez-Limón, J.A.; Riesgo, L. Irrigation water pricing: Differential impacts on irrigated farms. Agric. Econ. 2004, 31, 47-66. [CrossRef]

29. Mushtaq, S.; Moghaddasi, M. Evaluating the Potentials of Deficit Irrigation as an Adaptive Response to Climate Change and Environmental Demand. Environ. Sci. Policy 2011, 14, 1139-1150. [CrossRef]

30. Benli, B.; Kodul, S. A Non-Linear Model for Farm Optimization with Adequate and Limited Water Supplies Application to the South-East Anatolain Project (GAP) Region. Agric. Water Manag. 2003, 62, $187-203$. [CrossRef]

31. Graveline, N.; Mérel, P. Intensive and extensive margin adjustments to water scarcity in France's Cereal Belt. Eur. Rev. Agric. Econ. 2014, 41, 707-743. [CrossRef]

32. Elahi, M.; Vakilpour, M.H.; Najafi Alamdarloo, H. Effect of Water Pricing and Allocation on Management of Groundwater Resources in Kabudarahang Plain. Water Res. Agric. 2018, 32, 267-283.

33. Asaadi, M.A.; Hahirahimi, M.; Mortazavi, S.A. The effects of restriction policy of agricultural water supply on cropping pattern: A Case Study of Dehgolan Plain in Kurdistan Province. Agric. Econ. Dev. 2018, in press.

34. Iran Water Resources Management. Available online: https://www.wrm.ir/index.php?l=EN (accessed on 8 February 2017).

35. Ministry of Agriculture Jihad. Available online: https://www.maj.ir/ (accessed on 25 August 2014).

36. Kurdistan Regional Water Authority. Annual Reports. Available online: Websitehttps://www.kdrw.ir/?l=EN (accessed on 16 December 2014).

37. Miraki, S.H.; Zanganeh, S.H.; Chapi, K.; Singh, V.; Shirzadi, A.; Shahabi, H.; Pham, B.T. Mapping Groundwater Potential Using a Novel Hybrid Intelligence Approach. Water Resour. Manag. 2018, 33, 281-302. [CrossRef]

38. Medellin-Azuara, J.; Harou, J.; Howitt, R. Estimating Economic Value of Agricultural Water under Changing Conditions and the Effects of Spatial Aggregation. Sci. Total Environ. 2010, 408, 5369-5648. [CrossRef]

39. Howitt, R.E. Agricultural and Environmental Policy Models: Calibration, Estimation, and Optimization. Master's Thesis, University of California, Davis, CA, USA, January 2005.

40. Cortignani, R.; Severini, S. Introducing Deficit Irrigation Crop Techniques Derived by Crop Growth into a Positive Mathematical Programming Model. In Proceedings of the 2008 International Congress, Ghent, Belgium, 26-29 August 2008. 
41. Paris, Q. Symmetric Positive Equilibrium Problem: A Framework for Rationalizing Economic Behavior with Limited Information. Am. J. Agric. Econ. 2001, 83, 1049-1061. [CrossRef]

42. Blanco, M.; Iglesias, E.; Sumpsi, J.M. Environmental and Socioeconomic Effect of Water Pricing Policies: Key Issues in the Implementation of the Water Framework Directive. In Proceedings of the 13th Annual EAERE Cinference, Budapest, Hungary, 25-28 June 2004.

43. Iglesias, E.; Blanco, M. New Directions in Water Resources Management: The Role of Water Pricing Policies. Water Resour. Res. 2008, 44, 1-11. [CrossRef]

44. Arfini, F.; Paris, Q. A Positive Mathematical Programming Model for Regional Analysis of Agricultural Policies. In Proceedings of the 40th Seminar of the European Association of Agricultural Economist, Ancona, Italy, 26-28 June 1995; pp. 17-35.

45. Howitt, R.E. Positive Mathematical Programming. Am. J. Agric. Econ. 1995, 77, 329-342. [CrossRef]

46. Paris, Q.; Montresor, E.; Arfini, F.; Mazzocchi, M. An integrated multi-phase Model for Evaluating Agricultural Policies through Positive Information. In Proceedings of the EAAE Seminar on Agricultural Sector Modeling, Bonn, Germany, 29-31 March 2000.

47. Arfini, F.; Donati, M.; Paris, Q. A National PMP Model for Policy Evaluation in Agriculture using Micro Data and Administrative Information. In Proceedings of the International Conference Agricultural Policy Reform and the WTO: Where Are We Heading? Capri, Italy, 23-26 June 2003.

48. Paris, Q. Cost function and positive mathematical programming. Bio-Based Appl. Econ. 2017, 6, 19-35.

49. Brooke, A.; Kendrick, D.; Meeraus, A. GAMS: A User's Guide; The Scientific Press: Redwood City, CA, USA, 1988.

50. Howitt, R.E.; Medellín-Azuara, J.; MacEwan, D.; Lund, J.R. Calibrating Disaggregate Economic Models of Agricultural Production and Water Management. Environ. Model. Softw. 2012, 38, 244-258. [CrossRef]

51. Paris, Q.; Howitt, R.E. An analysis of Ill-Posed Production Problems using Maximum Entropy. Am. J. Agric. Econ. 1998, 80, 124-138. [CrossRef]

52. Heckelei, T.; Wolff, H. Estimation of Constrained Optimisation Models for Agricultural Supply Analysis Based on Generalised Maximum Entropy. Eur. Rev. Agric. Econ. 2003, 30, 27-50. [CrossRef]

53. Heckelei, T. Shadow Prices in PMP and Consequences for Calibration and Estimation of Programming Models. In Proceedings of the International Congress, Copenhagen, Denmark, 23-27 August 2005.

54. Heckelei, T. Calibration and Estimation of Programming Models for Agricultural Supply Analysis. Ph.D. Thesis, University of Bonn, Bonn, Germany, January 2002.

55. Shephard, R. Theory of Cost and Production Functions; Princeton University Press: Princeton, NJ, USA, 1970.

56. Esteban, E.; Albiac, J. Groundwater and Ecosystems Damages: Questioning the Gisser-Sánchez effect. Ecol. Econ. 2011, 70, 2062-2069. [CrossRef]

57. Yazdani, S.; Mahmodi, A.; Yavari Gh Shokat Fadayi, M.; Nazari, M.; Mirzaei, M. Analysis of the Economic Effects of Nonprice Policy Reduced Water Supply in Qazvin Plain. Q. J. Econ. Growth Dev. Res. 2016, 6, 89-98.

58. Mirzaei, K.; Ahmadpour Borazjani, M. Effects of Irrigation Water Quotation on Cropping Pattern and Farmers' Gross Margin in Amol Region. Iran-Water Resour. Res. 2016, 12, 166-179.

59. Matanga, G.B.; Marino, M.A. Irrigation Planning: Cropping pattern. Water Resour. Res. 1979, 15, $672-678$. [CrossRef]

60. Sharma, R.K.; Sankhayan, P.L.; Singh, R. Analysis of Profitability and Risk in New Agriculture in a Himalayan watershed by using Dynamic Non-Linear Programming Model. In Proceedings of the International Association Agricultural Economists Conference, Beijing, China, 16 August 2009.

61. Pfeiffer, L.; Lin, C. Groundwater Pumping and Spatial Externalities in Agriculture. J. Environ. Econ. Manag. 2012, 64, 16-30. [CrossRef]

(C) 2019 by the authors. Licensee MDPI, Basel, Switzerland. This article is an open access article distributed under the terms and conditions of the Creative Commons Attribution (CC BY) license (http://creativecommons.org/licenses/by/4.0/). 